\title{
Characteristics of random amplified polymorphic DNA markers discriminating Helianthus annuus inbred lines
}

\author{
B Teulat *, YX Zhang **, P Nicolas $\dagger$ \\ Unité associée université Blaise-Pascal - INRA, organisation et variabilité des génomes végétaux, \\ 4, rue Ledru, F63038 Clermont-Ferrand cedex, France \\ (Received 11 March 1994; accepted 2 November 1994)
}

\begin{abstract}
Summary - Random amplified polymorphic DNA (RAPD) markers were used to discriminate between inbred lines of the sunflower Helianthus annuus. By testing one hundred 10-mer primers with DNAs from 4 lines, we obtained 40 primers showing polymorphism in at least one line. After selection of primers giving reproducible signals, 14 RAPD markers allowing the characterization of inbred lines of sunflower were obtained. Molecular studies of amplified fragments show that these markers are of the "presence/absence" type: a locus is characterized by 1 band for a line and by the lack of band for the other lines. Southern experiments with polymorphic RAPD fragments as probes gave smears as hybrization signals, indicating that the amplified fragments probably include highly repeated sequences.
\end{abstract}

Helianthus annuus = sunflower / genetic markers / RAPD / RFLP

Résumé - Caractéristiques des marqueurs RAPD permettant la discrimination de lignées d'Helianthus annuus. Nous avons testé l'utilisation de marqueurs RAPD (random amplified polymorphic DNA) pour permettre la discrimination de lignées de tournesol cultivé Helianthus annuus. En testant 100 amorces décamères sur les ADN de 4 lignées, nous obtenons 40 amorces révélant un polymorphisme. Nous montrons qu'en sélectionnant les amorces donnant des signaux reproductibles on obtient 14 marqueurs RAPD permettant de caractériser des lignées de tournesol. L'étude moléculaire des fragments amplifiés montre que ces marqueurs sont de type "présence/absence" : un locus est caractérisé par une bande chez une lignée et l'absence de bande chez les autres lignées. Des expériences de Southern utilisant des fragments RAPD polymorphes comme sondes produisent des signaux d'hybridation en trainée, indiquant que les fragments amplifiés renferment vraisemblablement des séquences hautement répétées.

Helianthus annuus = tournesol/ marqueurs génétiques $/$ RAPD $/$ RFLP

\footnotetext{
* Present address: INRA-ENSAM, 2 place Viala, F34060 Montpellier, France.

** Present address: Geves, Le Magneraud, Saint-Pierre-d'Amilly, BP 52, F17700 Surgères, France.

† Correspondence and reprints.
} 


\section{INTRODUCTION}

Molecular markers have proved to be an attractive and powerful tool for plant breeding programmes in genetic mapping, variety identification and germplasm studies. Isozymes and restriction fragment length polymorphism (RFLPs) markers were until recently the most used markers. After the discovery of random amplified polymorphic DNA markers (RAPDs) by Williams et al (1990) and Welsh and McClelland (1990), this polymerase chain reaction (PCR)-based new class of molecular markers has quickly proved to be an interesting alternative for varietal identification (Caetano-Anollès et al, 1991; Hu and Quiros, 1991; Welsh et al, 1991), phylogenetic studies (Tulsieram et al, 1992), and mapping (Carlson et al, 1991; Klein-Lankhorst et al, 1991; Martin et al, 1991; Michelmore et al, 1991) because of the simplicity of the technique, the low quantity of target DNA necessary for genetic analysis and the possibility of automatization.

In the Helianthus genus and in the sunflower Helianthus annuus, isozymes have been used for line characterization (Quillet et al, 1991) and phylogenetic studies (Rieseberg et al, 1991). RFLPs have been reported in phylogenetic studies (Gentzbittel et al, 1992) and line descriptions (Gentzbittel et al, 1994a). A RFLP linkage map of cultivated sunflower has recently been constructed in our laboratory (Gentzbittel et al, 1994b). Rieseberg et al (1993) have also reported the construction of a genetic map by using RAPD markers in $H$ anomalus, a diploid species possibly derived via hybridization between $H$ annuus and $H$ petiolaris. However, RAPD strategy has never been explored in the cultivated sunflower.

We report here the application of RAPD markers for the intraspecific identification of cultivated inbred lines of sunflower ( $H$ annuus $L$ ) and some molecular characteristics of RAPD fragments.

\section{MATERIALS AND METHODS}

\section{Plant material}

Seventeen cultivated sunflower ( $H$ annuus $L)$ inbred lines (HA89, H52, 2603, 89B1, GH, SD, 227362, HA124, HA300, RHA274, PB3, PAC2, PX7, RHA266, RHA345, CANP3 and PAT4 ) obtained from $F$ Vear (INRA, Clermont-Ferrand, France) were used for RAPD analysis.

\section{DNA extraction}

DNA was extracted from sunflower green leaves according to the CTAB protocol of Rogers and Bendich (1985) with minor modifications.

\section{RAPD analysis}

PCR amplification conditions were defined after testing various Taq polymerase sources (Appligene, Boehringer, Perkin-Elmer, Promega) and concentrations (from 0.5 to $2 \mathrm{U} / \mu \mathrm{l}$ ), $\mathrm{MgCl}_{2}$ concentrations (from 1 to $10 \mathrm{mM}$ ), template DNA concentrations (from 50 to $400 \mathrm{ng} / 50 \mu \mathrm{l}$ amplification mix) and amplification cycles. The following protocol was chosen. Amplification reactions were performed in $50 \mu \mathrm{l}$ ali-

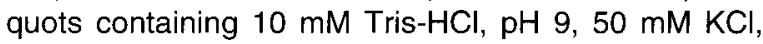
$3 \mathrm{mM} \mathrm{MgCl} 2,0.2 \mathrm{mg} / \mathrm{ml}$ gelatin, $100 \mu \mathrm{M}$ of each dNTP, $0.2 \mu \mathrm{M}$ primer (10-mers from Operon Technologies Inc, Almeda, CA, USA), 100 ng DNA and 1 unit of Taq DNA polymerase Appligene. A Perkin-Elmer Cetus DNA thermal cycler 9600 was used, programmed for 1 initial denaturation step for $5 \mathrm{~min}$ at $93^{\circ} \mathrm{C}, 40$ cycles of amplification of $1 \mathrm{~min}$ at $91^{\circ} \mathrm{C}, 1 \mathrm{~min}$ at $36^{\circ} \mathrm{C}$ and 2 min at $70^{\circ} \mathrm{C}$, and one terminal extension step of $5 \mathrm{~min}$ at $70^{\circ} \mathrm{C}$. Amplification products were analyzed after electrophoresis in $1.4 \%$ agarose gels and ethidium bromide staining.

\section{Conversion of RAPD amplification product to $R F L P$ probes}

Some of the RAPD fragments were excised from low melting agarose gels, purified by a Magic PCR DNA purification system (Promega) then used as probes for RFLP analysis. Procedures for RFLP analysis were as described by Gentzbittel et al (1994a). DNAs from the 17 sunflower lines were digested with either Hindll or EcoRl.

\section{RESULTS AND DISCUSSION}

\section{Screening of random primers useful for characterization of sunflower inbred lines}

One hundred decamer primers of random sequences (Operon kits $C, E, J, M$ and $S$ ) were tested with DNA from 4 lines (RHA266, HA300, HA89 and PAC2). The amplified DNA fragments obtained ranged from 200 to 3000 bp. Usually, more than 10 bands were detected. However, most were weakly amplified (faint bands), so the number of major bands varied from 1 to 4 . Some major bands were common to 
the 4 lines while others were specific to 1 line. This demonstrates that polymorphisms between amplification products of the 4 lines can be detected. Forty percent of the primers detected polymorphism (at least 1 line different from the others), $29 \%$ were monomorphic, $19 \%$ produced no amplification and $12 \%$ gave smears.

Low reproducibility is known as the major problem using RAPD markers. The experiments described above were repeated 3 times with the same DNA extract. The primers giving the same pattern for the 3 replicates were selected and will be called RAPD markers in the following sections. Among the 100 primers tested (Operon kits C, E, J, M and S), only 14 produced RAPD markers with polymorphic and reproducible signals: primers $\mathrm{C16}, \mathrm{E} 06, \mathrm{E} 07$, E08, E19, J09, J14, J19, M02, M06, M13, M16, M18 and S18.

Some RAPD markers were tested to characterize 17 inbred lines of cultivated sunflower. As shown in figure 1 , the bands obtained with only 4 RAPD markers allow us to distinguish the lines from one another. It is thus possible to select a set of random primers to characterize different lines of cultivated sunflower.

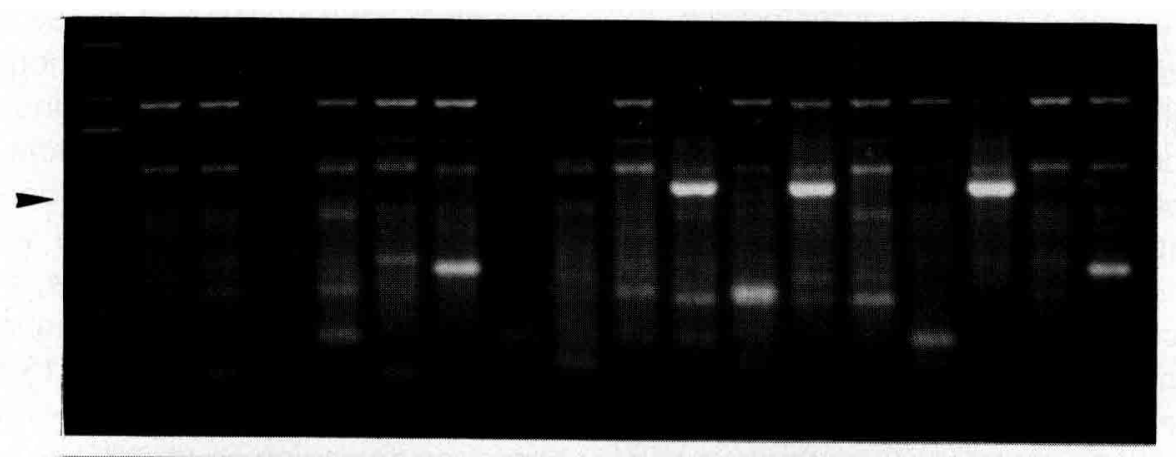

$\mathbf{A}$
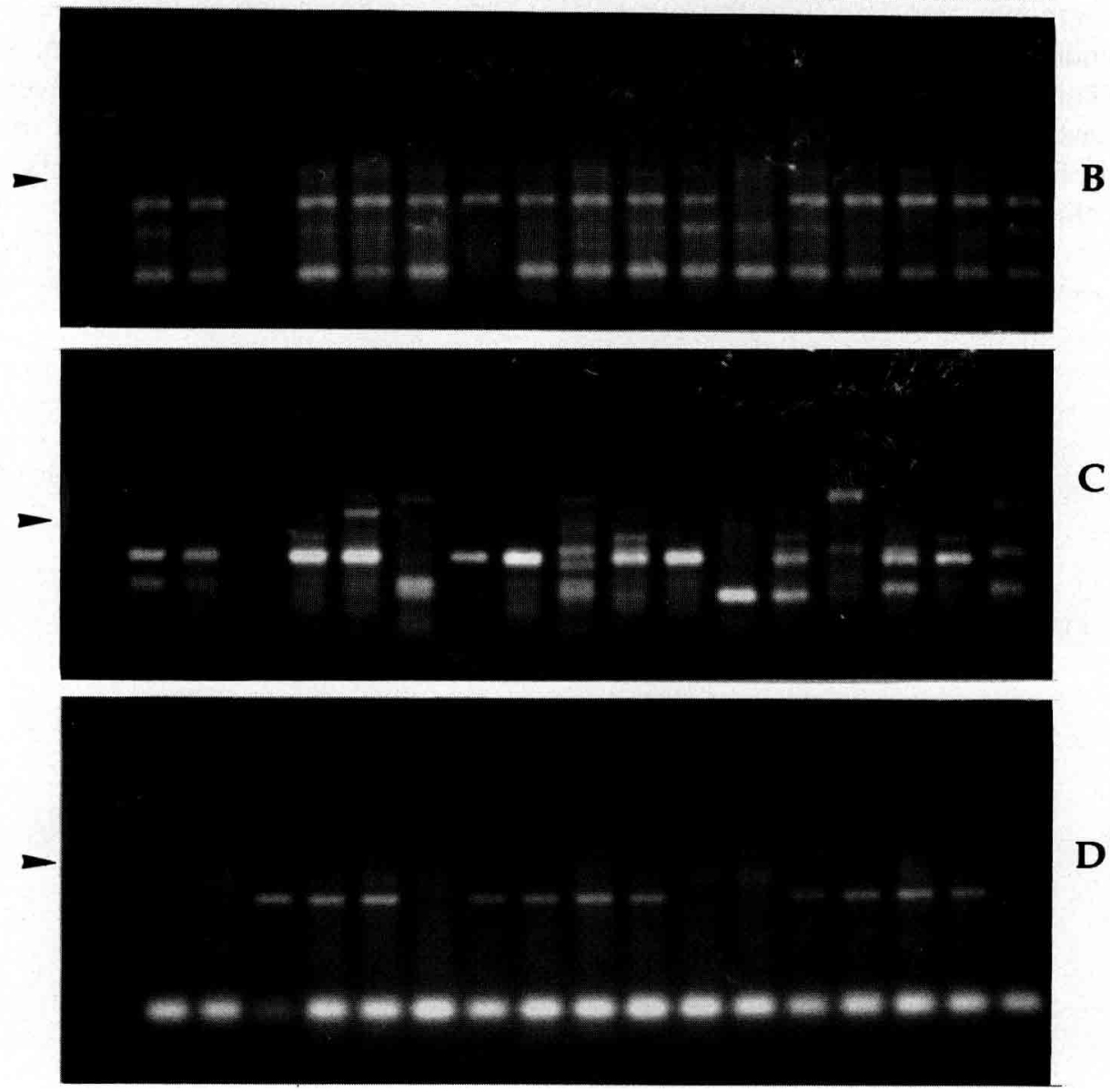

Fig 1. Characterization of inbred lines of sunflower with RAPD markers; amplification of DNA from 17 inbred lines of sunflower is shown. From left to right: molecular size markers (BRL DNA ladder; the arrow indicates the position of the $1 \mathrm{~kb}$ fragment), amplification with DNAs from inbred lines PB3, H52, 2603, 89B1, GH, Z2736.2, HA124, HA300, RHA274, HA89, PAC2, PX7, RHA266, RHA345, CANP3 and PAT4. The primers used were: A) OPJ01; B) OPJ04; C) OPE17; and D) OPC16. 


\section{Molecular analysis of RAPD fragments}

Genetic studies have shown that RAPD fragments are often dominant markers (Rafalski et al, 1991). In this case, for each locus the RAPD assays detect the presence of only 1 allele, that giving an amplification; the absence of an amplified band on the other genotypes represents all the other alleles at that locus that fail to prime amplification. To assess whether it is also the case for RAPD markers on sunflower lines, electrophoresis gels of RAPD amplification products have been made in duplicate. One of the gel was blotted onto a Hybond $\mathrm{N}^{+}$filter; some fragments of the other gel were excised, labeled with ${ }^{32} \mathrm{P}$ and then used as probes onto the filter (data not shown). When the probe was a monomorphic fragment (identical from 1 line to another), this fragment was labeled at the same position for all the lines, indicating that the segment of DNA amplified was the same for the different genotypes. In contrast, when the probe was a polymorphic fragment (present on one line but not observed for the others at the same position) none of the fragments amplified from the other lines were hybridized. These results indicate that the polymorphism revealed by RAPD markers between sunflower lines agrees with the 'present vs absent' type. For 1 locus only 1 allelic form is amplified; the others are not. Genetic studies on
F2 segregants confirm the dominant status of RAPD markers (data not shown).

To study the type of sequences amplified with random primers, we have used random amplified fragments as probes for Southern blot analyses. Amplified fragments were excised from gels after electrophoresis, radiolabeled then hybridized to filters containing DNA from 17 lines digested with 2 restriction enzymes, EcoRl or Hindll. When polymorphic fragments were used as probes, in most cases they gave smears on Southern blots (data not shown). This indicates that these amplified products contained repeated sequences present in numerous loci in the genome, as observed in lettuce (Paran et al, 1993; Kesseli et al, 1994). Only one of the 20 polymorphic fragments tested in this study gave a simple but monomorphic signal on Southern blots, as shown in figure 2A. When monomorphic bands were used as probes, they often produced single hybridization signals on Southern blots, indicating that they correspond to unique sequences in the sunflower genome. Three of the 13 monomorphic fragments used revealed polymorphism between lines, as shown on figure $2 \mathrm{~B}$ with the example of the fragment OPS18-3. Thus, some random amplified fragments can be converted into RFLP probes, with the unexpected result that only monomorphic RAPD fragments can generate polymorphic RFLP probes.
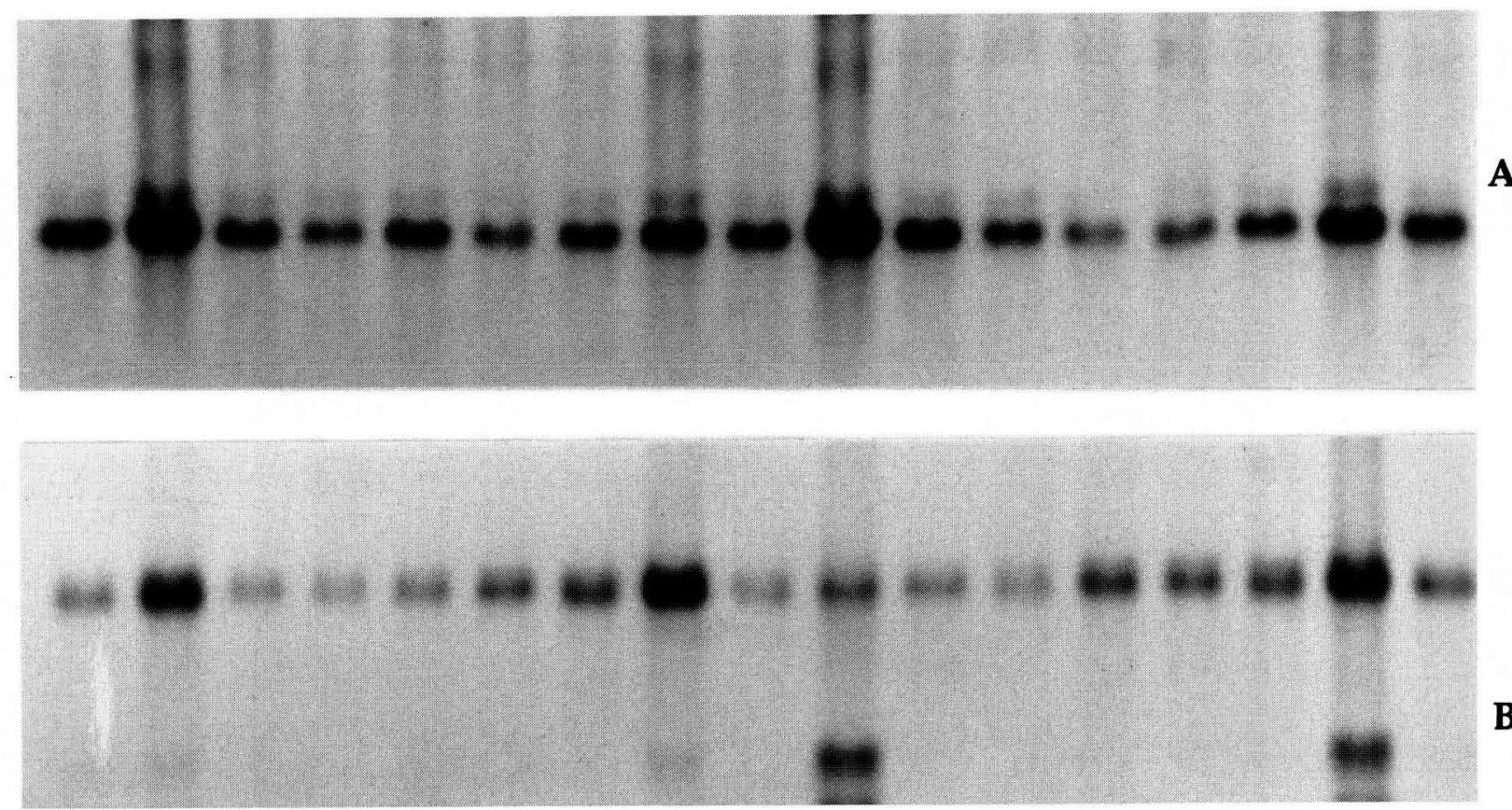

Fig 2. Use of RAPD amplification products as RFLP probes. DNAs from sunflower lines were digested with EcoRI, separated on a $0.8 \%$ agarose gel and blotted onto Hybond- $\mathrm{N}^{+}$. Southern blots were hybridized with radiolabeled PCR products obtained with random primers. From left to right: hybridizations on digests from lines: PB3, H52, 2603, 89B1, GH, SD, Z2736.2, HA124, HA300, RHA274, HA89, PAC2, PX7, RHA266, RHA345, CANP3 and PAT4. A) Hybridization with the polymorphic PCR product OPJ04-2 as probe; and B) hybridization with the monomorphic PCR product OPS18-3 as probe. 


\section{CONCLUSION}

In previous work, we showed that RFLP markers can be used to characterize species of the Helianthus genus (Gentzbittel et al, 1992) or inbred lines of the cultivated sunflower $H$ annuus (Gentzbittel et al, 1994a). In the present work we showed that RAPD markers, described by Rieseberg et al (1993) as usable for genetical mapping in interspecific crosses, can be used for discrimination between inbred lines of sunflower.

Compared with RFLP markers, RAPD markers present 2 deficiencies. The first is the weak reproducibility from 1 experiment to another, as discussed by Ellsworth et al (1993). Indeed, we observed that only a third of the random primers producing a simple and polymorphic signal gave reproducible amplifications. Thus, only $14 \%$ of the random primers tested can be used as reproducible polymorphic markers. However, as hundreds of random primers are potentially available, it is possible to find numerous useful RAPD markers. In addition, our results show that a small number of markers is sufficient to some applications such as discrimination between inbred lines. To obtain more precise and reproducible markers corresponding to amplified RAPD products, it is also possible, after partial sequencing of the ends of the amplified fragments, to get specific primers for each end. Such PCR-amplified fragments were called SCARs (sequencecharacterized amplified regions) by Paran and Michelmore (1993).

The second deficiency of RAPD markers, when used for genetic studies such as construction of chromosome maps, is that they reveal polymorphism of the 'presence/absence' type and segregate as dominant alleles, as reported in broccoli and cauliflower (Hu and Quiros, 1991), lettuce (Michelmore et al,1991) or canola (Deragon and Landry 1992). In this study we also observed the 'presence/absence' type of polymorphism with RAPD fragments obtained from sunflower inbred lines. Thus in crosses it is impossible to distinguish between heterozygous and homozygous genotypes with the amplified fragment. RAPD markers are therefore less informative than codominant RFLP markers (Roy et al, 1992).

In spite of these disavantages, RAPD markers may be useful for genetic studies of inbred lines of sunflower. Experiments are simple and fast to perform, they do not need radioactivity and only small amounts of plant material are required.
Our results show that RAPD markers can be used for characterization of lines, allowing classification and phylogenetic studies. Furthermore, they can provide additional markers to the sunflower RFLP chromosome map in progress in our laboratory (Gentzbittel et al, 1994b). Indeed, we have demonstrated here that RAPD markers reveal polymorphism on DNA segments including highly repeated sequences, wheras RFLP markers correspond to unique or weakly repeated sequences (Gentzbittel et al, 1994a). RAPD markers may thus map on chromosomal segments distinct from those where RFLP markers are localized.

\section{ACKNOWLEDGEMENTS}

We would like to thank $L$ Gentzbittel, A Perrault, V De Conto, S Haby and M Hadonou for technical advice and helpful discussions, and $P$ Drevet for her critical reading of the manuscript.

\section{REFERENCES}

Caetano-Anollés G, Bassam BJ, Gresshiff PM (1991) DNA amplification fingerprinting: a strategy for genome analysis. Bio/Technology 9, 553-557

Carlson JE, Tulsieram LK, Glaubitz JC, Luk VWK, Kauffeld C, Rutledge R (1991) Segregation of random amplified DNA markers in $F 1$ progeny of conifers. Theor Appl Genet 83, 194-200

Deragon JM, Landry BS (1992) RAPD and other PCRbased analyses of plant genomes using DNA extracted from small leaf disks. PCR Methods Appl $1,175-180$

Ellsworth DL, Rittenhouse KD, Honeycutt RL (1993) Artifactual variation in randomly amplified polymorphic DNA banding patterns. Bio/Technology 14, 214-217

Gentzbittel L, Perrault A, Nicolas P (1992) Molecular phylogeny of the Helianthus genus, based on nuclear restriction fragment length polymorphism (RFLP). Mol Biol Evol 9, 872-892

Gentzbittel L, Zhang YX, Vear F, Griveau Y, Nicolas $P$ (1994a) RFLP studies of genetic relationships among inbred lines of cultivated sunflower, Helianthus annuus L: evidence for distinct restorer and maintainer germplasm pools. Theor App/ Genet 89, 419-425

Gentzbittel L, Vear F, Bervillé A, Zhang YX, Nicolas $P$ (1994b) Le programme Cartisol : une carte génétique pour le tournesol. Oléoscope 19, 24-27

$\mathrm{Hu}$ J, Quiros CF (1991) Identification of broccoli and cauliflower cultivars with RAPD markers. Plant Cell Reports 10, 505-511

Kesseli RV, Paran I, Michelmore RW (1994) Analysis of a detailed genetic linkage map of Lactuca sativa 
(lettuce) constructed from RFLP and RAPD markers. Genetics 136, 1435-1446

Klein-Lankhorst RM, Vermunt A, Weide R, Liharska T, Kabel P (1991) Isolation of molecular markers for tomato ( $L$ esculentum) using amplified polymorphic DNA ( RAPD ). Theor App/ Genet 83, 108-114

Martin GB, Williams JGK, Tanksley SD (1991) Rapid identification of markers linked to a Pseudomonas resistance gene in tomato by using random primers and near-isogenic lines. Proc Natl Acad Sci USA $88,2336-2340$

Michelmore RW, Paran I, Kesseli RV (1991) Identification of markers linked to disease resistance genes by bulked segregant analysis: a rapid method to detect markers in specific genomic regions by using segregating populations. Proc Natl Acad Sci USA 88, 9828-9832

Paran I, Michelmore RW (1993) Development of reliable PCR-based markers linked to downy mildew resistance genes in lettuce. Theor App/ Genet 85, 985-993

Quillet MC, Vear F, Branlard G (1991) The use of isoenzymes polymorphism for identification of sunflower (Helianthus annuus $L$ ) inbred lines. $J$ Genet \& Breed 46, 295-304

Rafalski JA, Tingey SV, Williams JGK (1991) RAPD markers: a new technology for genetic mapping and plant breeding. Ag Biotech News and Information 3, 645-648
Rieseberg LH, Beckstrom-Sternberg SM, Liston A, Arias DM (1991) Phylogenetic and systematic inferences from chloroplast DNA and isozyme variation in Helianthus sect Helianthus (Asteraceae). Syst Bot 16, 50-76

Rieseberg LH, Choi H, Chan R, Spore C (1993) Genomic map of a diploid hybrid species. Heredity 70, 285-293

Rogers S, Bendich A (1985) Extraction of DNA from milligram amounts of fresh, herbarium and mummified plant tissues. Plant Mol Biol 5, 69-76

Roy A, Frascaria N, Mac Kay J, Bousquet J (1992) Segregrating random amplified polymorphic DNAs (RAPDs). Theor Appl Genet 85, 173-180

Tulsieram LK, Glaubitz JC, Kiss G, Carlson JE (1992) Single tree genetic linkage mapping in conifers using haploid DNA from megagametophytes. Bio/Technology 10, 686-689

Welsh J, Mc Clelland M (1990) Fingerprinting genomes using PCR with arbitrary primers. NuCl Acids Res 18, 7213-7218

Welsh J, Honeycutt RJ, McClelland M, Sobral BWS (1991) Parentage determination in maize hybrids using the arbitrarily primed polymerase reaction (AP-PCR). Theor Appl Genet 82, 473-476

Williams JGK, Kubelik AR, Livak KJ, Rafalski JA, Tingey SV (1990) DNA polymorphisms amplified by arbitrary primers are useful as genetic markers. Nucl Acids Res 18, 6531-6535 